\title{
PENGARUH JUS MENTIMUN TERHADAP PENURUNAN TEKANAN DARAH PADA PENDERITA HIPERTENSI
}

\section{THE EFFECT OF CUCUMBER JUICE CONSUMPTION ON REDUCTION OF BLOOD PRESSURE IN HYPERTENSION PATIENTS}

\author{
${ }^{1}$ Fitra Pringgayuda, ${ }^{2}$ Cikwanto, Zam Zami Hidayat ${ }^{3}$ \\ ${ }^{123}$ Universitas Muhammadiyah Pringsewu \\ Email : fpringgayuda@yahoo.com
}

\begin{abstract}
The Effect Of Cucumber Juice Consumption On Reduction Of Blood Pressure In Hypertension Patients. Hypertension is a condition where a person experiences an increase in blood pressure above normal which results in an increase in morbidity and mortality. In Indonesia, 26.5\% had hypertension from the total population of Indonesia. There have been many efforts made to deal with this problem, one of which is to consume cucumber juice. This study aims to determine the effect of cucumber juice consumption on reducing blood pressure in patients with hypertension.This study uses the Quasy Experiment method with the design of Non Equivalent Control Group. The sampling technique used Purposive Sampling with 22 respondents consisting of intervention and control groups. The intervention group was given cucumber juice 2 times a day, morning and evening with a composition of pure cucumber as much as $250 \mathrm{ml}$. Data analysis using dependent $\mathrm{T}$ test.The results showed that there was an effect of cucumber juice consumption on reducing blood pressure in hypertensive patients with a $p$ value of 0,000 ( $p$ value $<0.05$ ) Efforts to reduce blood pressure will be better if combined with other measures such as massage therapy, regular exercise and so on to be more effective in lowering blood pressure.

Keywords : Consumption of Cucumber Juice, Hypertension, Decreased Blood Pressure
\end{abstract}

\begin{abstract}
Abstrak: Pengaruh Jus Mentimun Terhadap Penurunan Tekanan Darah Pada Penderita Hipertensi Hipertensi adalah suatu keadaan dimana seseorang mengalami peningkatan tekanan darah diatas normal yang mengakibatkan peningkatan kesakitan (morbiditas dan angka kematian (mortalitas). Di Indonesia sendiri telah tercatat sebanyak 26,5\% telah mengalami hipertensi dari total penduduk Indonesia. Telah banyak upaya yang dilakukan untuk menangani masalah ini, salah satunya ialah dengan mengkonsumsi jus mentimun. Penelitian ini bertujuan untuk mengetahui pengaruh konsumsi jus mentimun terhadap penurunan tekanan darah pada penderita hipertensi.Penelitian ini menggunakan metode Quasy Eksperiment dengan rancangan Non Equivalent Control Group. Teknik pengambilan sampel manggunakan Purposive Sampling sejumlah 22 responden terdiri dari kelompok intervensi dan control. Kelompok intervensi diberikan jus mentimun 2 kali sehari, pagi dan sore hari dengan komposisi buah mentimun murni sebanyak $250 \mathrm{ml}$. Analisis data menggunakan uji T dependen.Hasil penelitian menunjukkan terdapat pengaruh konsumsi jus mentimun terhadap penurunan tekanan darah pada penderita hipertensi dengan nilai $p$ value 0,000 ( $p$ value $<0,05$ ). Upaya menurunkan tekanan darah akan lebih baik jika dikombinasikan dengan tindakan lain seperti terapi massage, olah raga rutin dan lain sebagainya agar lebih efektif untuk menurunkan tekanan darah.

Kata kunci : Konsumsi Jus mentimun, Hipertensi, Penurunan tekanan darah
\end{abstract}

\section{PENDAHULUAN}

Menurut American Heart Association(AHA), penduduk Amerika yang berusia diatas 20 tahun menderita hipertensi telah mencapai angka hingga 74,5 juta jiwa, namun hampir sekitar 
90-95\% kasus tidak diketahui penyebabnya. Berdasarkan data dari WHO tahun 2010, dari 50\% penderita hipertensi yang diketahui hanya $25 \%$ yang mendapat pengobatan, dan hanya $12,5 \%$ yang diobati dengan baik. Sekitar $80 \%$ kenaikan kasus hipertensi terjadi terutama di negara berkembang.

Penderita hipertensi juga menyerang Thailand sebesar $17 \%$ dari total penduduk, Vietnam34,6\%, Singapura 24,9\%, Malaysia 29,9\%, dan Indonesia memiliki angka yang cukup tinggi, yaitu15\% dari 230 juta penduduk Indonesia terkena hipertensi (Susilo dkk, 2011). Prevalensi hipertensi diIndonesia yang didapat melalui pengukuran pada umur $\geq 18$ tahun sebesar 25,8\% (Riskesdas, 2013). Kejadian hipertensi di Lampung mencapai 24,7\%. Hasil tersebut lebih tinggi dari provinsi yang terdekat seperti Jambi yang hanya 24,6\% dan Bengkulu 21,6\% (Riskesdas, 2013). Sedangkan prevalensi hipertensi di Kabupaten Pringsewu, berdasarkan umur $\geq 18$ tahun sebanyak 2167 orang atau 21,80\% mengalami hipertensi, berdasarkan jumlah jenis kelamin laki-laki dan perempuan (Dinkes, 2015).

Desa Way Ngison merupakan wilayah kerja Puskesmas Pagelaran yang memiliki luas wilayah $2555 \mathrm{~m}^{2}$. Berdasarkan data pra-survei yang dilakukan oleh peneliti pada tanggal 26 Februari 2018 melalui ibu Agus Setia Ningsih yang bertugas sebagai bidan desa di Desa Way Ngison, didapat 27 orang yang mengalami hipertensi. Dari 27 orang tersebut, 7 orang diantaranya telah mengetahui tentang mengkonsumsi mentimun dapat membantu menurunkan tekanan darah dan 4 orang diantaranya telah merasakan perubahan yaitu tekanan darahnya turun setelah mengkonsumsi mentimun.

Faktor resiko hipertensi menurut lembaga Pusat Data dan Informasi (Infodatin, 2014) adalah umur, jenis kelamin, riwayat keluarga, genetik (faktor resiko yang tidak dapat diubah/dikontrol), kebiasaan merokok, konsumsi garam, konsumsi lemak jenuh, penggunaan jelantah, kebiasaan konsumsi minum-minuman beralkohol, obesitas, kurang aktifitas fisik, stress, penggunaan estrogen. Salah satu faktor risiko yang dapat dikelola adalah pengendalian asupan makanan. Modifikasi asupan bahan makanan yang mengandung kalium dan magnesium menjadi salah satu terapi komplementer untuk menurunkan tekanan darah, baik sistolik maupun diastolik. Rekomendasi asupan kalium dan magnesium menurut International Food Information Council Foundation dan North Carolina DieteticAssociation untuk kalium $4700 \mathrm{mg}$ dan magnesium $400 \mathrm{mg}$.

Hipertensi dapat diobati dengan terapi farmakologis maupun non-farmakologis. Salah satu terapi non-farmakologis untuk menangani hipertensi yaitu dengan mengkonsumsi jus mentimun. Hasil penelitian Zauhani Kusnul dan Zainal Munir (2011) dan Yuniati Valentina (2010) menyimpulkan ada pengaruh bermakna (signifikan) dari pemberian jus mentimun terhadap penurunan tekanan darah (Tjiptaningrum \& Erhadestria, 2016). Penelitian tentang pengaruh pemberian jus mentimun (Cucumis sativus L.) terhadap tekanan darah sistolik dan diastolik pada penderita hipertensi yg dilakukan oleh Lovindy Putri Lebalado tahun 2014 dengan sampel sebanyak 38 orang dan dibagi dalam dua kelompok, yaitu kelompok kontrol dan kelompok perlakuan. Setelah dilakukan penelitian selama 7 hari, penurunanyang terjadipada kelompokperlakuanadalah sebesar $12 \%$ untuktekanandarahsistolikdan10,4\% untuk diastolik. 


\section{METODE}

Penelitian ini adalah Quasi Eksperimen yang bertujuan untuk mengetahui pengaruh konsumsi jus mentimun terhadap penurunan tekanan darah pada penderita hipertensi.Jenis pendekatan atau rancangan yang digunakan pada penelitian ini adalah Non Equivalent Control Group.Populasi yang diambil pada penelitian ini adalah masyarakat yang menderita hipertensi di desa Way Ngison.Metode sampling yang digunakan dalam penelitian ini yaitu Purposive Sampling.Jumlah sampel sebanyak 21 responden.Penelitian ini dilaksanakan pada bulan Agustus tahun 2018.Pada penelitian ini responden dibagi dalam dua kelompok, yaitu kelompok intervensi dan kelompok kontrol.Instrumen yang digunakan lembar observasi, dan alat ukur berupa Tensimeter dan Stetoskop untuk pengukuran tekanan darah.Pengambilan data menggunakan lembar observasi dan pengukuran tekanan darah secara langsung. Analisis yang digunakan untuk mengetahui pengaruh konsumsi mentimun terhadap penurunan tekanan darah pada penderita hipertensidengan menggunakan uji $T$ Test Dependen (berpasangan).

\section{HASIL}

\section{Karakteristik Responden Berdasarkan Jenis Kelamin}

Tabel 4.1 Distribusi Frekuensi Karakteristik Responden Berdasarkan Jenis Kelamin AntaraKelompok Intervensi dan Kontrol Yang Mengalami Hipertensi di Desa Way Ngison

\begin{tabular}{ccc}
\hline Jenis kelamin & Frekuensi & Persentase \\
\hline Laki-laki & 2 & $9.1 \%$ \\
Perempuan & 20 & $90,9 \%$ \\
Jumlah & 22 & $100 \%$ \\
\hline
\end{tabular}

Berdasarkan hasil penelitian pada tabel 4.1 dapat dilihat distribusi frekuensi karakteristik responden berdasarkan jenis kelamin yg mengalami hipertensi paling banyak pada perempuan yaitu 20 orang $(90,9 \%)$ dan laki-laki hanya 2 orang $(9.1 \%)$.

\section{Karakteristik Responden Berdasarkan Tingkat Pendidikan}

Tabel 4.2

Distribusi Frekuensi Karakteristik Responden Berdasarkan Tingkat Pendidikan Antara Kelompok Intervensi dan Kontrol Yang Mengalami Hipertensi di Desa Way Ngison

\begin{tabular}{ccc}
\hline Tingkat Pendidikan & Frekuensi & Persentase \\
\hline Tidak Sekolah & $\mathbf{4}$ & $\mathbf{1 8 , 2 \%}$ \\
SD & $\mathbf{1 5}$ & $\mathbf{6 8 , 2 \%}$ \\
SMP & $\mathbf{3}$ & $\mathbf{1 3 , 6 \%}$ \\
Jumlah & $\mathbf{2 2}$ & $\mathbf{1 0 0 \%}$ \\
\hline
\end{tabular}

Berdasarkan hasil penelitian pada tabel 4.2 dapat dilihat distribusi frekuensi karakteristik responden berdasarkan tingkat pendidikan yg mengalami hipertensi paling banyak pada tingkat SD yaitu 15 orang $(68,2 \%)$ dan paling sedikit pada tingakat SMP yaitu 3 orang $(13,6 \%)$. 
Vol 10 No 1 Januari 2021 | Page 22-32

Karakteristik Responden Berdasarkan Pekerjaan

Tabel 4.3 Distribusi Frekuensi Karakteristik Responden Berdasarkan Pekerjaan Antara Kelompok Intervensi dan Kontrol Yang Mengalami Hipertensi di Desa Way Ngison

\begin{tabular}{ccc}
\hline Tingkat Pendidikan & Frekuensi & Persentase \\
\hline Tidak Bekerja & $\mathbf{5}$ & $\mathbf{2 2 , 2 \%}$ \\
IRT & $\mathbf{1 2}$ & $\mathbf{5 4 , 5 \%}$ \\
Petani & $\mathbf{3}$ & $\mathbf{1 3 \%}$ \\
Pedagang & $\mathbf{2}$ & $\mathbf{9 \%}$ \\
Jumlah & $\mathbf{2 2}$ & $\mathbf{1 0 0 , 0 \%}$ \\
\hline
\end{tabular}

Berdasarkan hasil penelitian pada tabel 4.3 dapat dilihat distribusi frekuensi karakteristik responden berdasarkan pekerjaan yg mengalami hipertensi paling banyak terjadi pada ibu rumah tangga (IRT) yaitu 12 orang $(54,5 \%)$ dan paling sedikit terjadi pada pedagang yaitu 2 orang $(9 \%)$.

\section{Gambaran Tekanan Darah Sistolik Sebelum dan Sesudah pada kelompok intervensi dan kontrol}

Tabel 4.4 Distribusi Perbedaan Mean (rata-rata) Sistolik Pada Kelompok Intervensi dan Kontrol Yang Mengalami Hipertensi di Desa Way Ngison

\begin{tabular}{|c|c|c|c|c|c|}
\hline Kelompok & $\mathbf{N}$ & Minimum & Maksimum & Mean & $\begin{array}{l}\text { Standar } \\
\text { Deviasi }\end{array}$ \\
\hline $\begin{array}{l}\text { Pre Tes } \\
\text { Intervensi }\end{array}$ & 11 & 140 & 190 & 168,8 & 17,215 \\
\hline $\begin{array}{l}\text { Post Tes } \\
\text { Intervensi }\end{array}$ & 11 & 120 & 160 & 137,27 & 11,909 \\
\hline $\begin{array}{l}\text { Pre Tes } \\
\text { Kontrol }\end{array}$ & 11 & 150 & 210 & 170,00 & 17,889 \\
\hline $\begin{array}{l}\text { Post Tes } \\
\text { Kontrol }\end{array}$ & 11 & 130 & 190 & 153,73 & 16,818 \\
\hline
\end{tabular}

Berdasarkan hasil penelitian pada tabel 4.4 dapat dilihat pada kelompok intervensi ratarata tekanan darah sistolik sebelum intervensi adalah 168,8 dengan nilai terendah 140 dan nilai tertinggi 190. Pada kelompok kontrol rata-rata tekanan darah sistolik sebelum intervensi adalah 170,00 dengan nilai terendah 150 dan nilai tertinggi 210. Pada kelompok intervensi rata-rata tekanan darah sistolik setelah intervensi adalah 137,27 dengan nilai terendah 120 dan nilai tertinggi 160. Pada kelompok kontrol rata-rata tekanan darah sistolik setelah intervensi adalah 153,73 dengan nilai terendah 130 dan nilai tertinggi 190.

\section{Hasil Analisis Bivariat}

Setelah diketahui karakteristik masing-masing variabel pada anlisis univariat maka dapat dilanjutkan dengan analisis bivariat untuk mengetahui apakah ada pengaruh konsumsi jus mentimun terhadap penurunan tekanan darah pada penderita hipertensi sebagai berikut : 
Vol 10 No 1 Januari 2021 | Page 22-32 Tabel 4.5 Pengaruh Konsumsi Jus Mentimun Terhadap Penurunan Tekanan Darah Pada
Penderita Hipertensi di Desa Way Ngison Tahun 2018

\begin{tabular}{|c|c|c|c|c|c|}
\hline Kelompok & $\mathbf{N}$ & Mean selisih & Mean & Standar Deviasi & Pvalue \\
\hline $\begin{array}{l}\text { Pre Tes } \\
\text { Intervensi }\end{array}$ & 11 & \multirow[t]{2}{*}{$-31,53$} & 168,8 & 17,215 & \multirow[t]{2}{*}{0.000} \\
\hline $\begin{array}{l}\text { Post Tes } \\
\text { Intervensi }\end{array}$ & 11 & & 137,27 & 11,909 & \\
\hline Pre Tes & 11 & \multirow[b]{2}{*}{$-16,27$} & 170,00 & 17,889 & \multirow{3}{*}{0.039} \\
\hline Kontrol & 11 & & & 16,818 & \\
\hline $\begin{array}{l}\text { Post Tes } \\
\text { Kontrol }\end{array}$ & & & & & \\
\hline
\end{tabular}

Bersarkan hasil penelitian pada tabel 4.5 dapat dilihat bahwa pemberian jus mentimun dapat menurunkan tekanan darah rata-rata sistolik -31,53 yaitu dari 168,8 (sebelum pemberian jus mentimun) kemudian turun menjadi 137,27 (sesudah pemberian jus mentimun). Sedangkan pada kelompok kontrol tekanan darah rata-rata sistolik -16,27 yaitu dari 170,00 kemudian turun menjadi 153,73. Hasil uji statistik diperoleh $p$ value 0,000 ( $p$ value $<0,05$ ) yg berarti terdapat pengaruh pemberian jus mentimun terhadpa penurunan tekanan darah pada penderita hipertensi di desa Way Ngison.

\section{PEMBAHASAN}

\section{Karakteristik Responden Jenis Kelamin}

Hasil penelitian menunjukkan responden yg mengalami hipertensi paling banyak pada perempuan yaitu 20 orang (90,9\%) dan laki-laki hanya 2 orang (9.1\%). Menurut Anggraini, 2009 dalam Prayoga, 2015 prevalensi terjadinya hipertensi pada pria sama dengan wanita. Tetapi wanita yang belum menopause dilindugi oleh hormon esterogen yang berperan dalam meningkatkan kadarHigh Density Lipoprotein $(H D L)$. Kadar kolesterol HDL yang tinggi merupakan faktor pelindung dalam mencegah terjadinya proses aterosklerosis. Pada premenopause mulai kehilangan sedikit demi sedikit hormon esterogen yang selama ini melindungi pembuluh darah dari kerusakan. Proses ini terus berlanjut dimana hormon esterogen tersebut berubah kuantitasnya sesuai dengan usia wanita secara alami, yang umumnya mulai terjadi pada wanita usia 45-55 tahun.

Menurut penelitian yang dilakukan oleh Novitaningtyas (2014).Jenis kelamin juga merupakan salah satu faktor yang mempengaruhi tekanan darah (Rosta, 2011 dalam Novitaningtyas, 2014).Perempuan cenderung menderita hipertensi daripada laki-laki. Pada penelitian tersebut sebanyak $27,5 \%$ perempuan mengalami hipertensi, sedangkan untuk laki-laki hanya sebesar $5,8 \%$. Perempuan akan mengalami peningkatan resiko tekanan darah tinggi (hipertensi) setelah menopouse yaitu usia diatas 45 tahun (Wahyuni \& Eksanoto, 2013 dalam Novitaningtyas, 2014).

Berdasarkan penelitian yang dilakukan oleh peneliti, jenis kelamin perempuan lebih banyak mengalami hipertensi karena tingkat stress pada perempuan lebih tinggi dibandingkan dengan laki-laki karena seseorang dengan kepribadian maskulin lebih mampu menghadapi 
Vol 10 No 1 Januari 2021 | Page 22-32

stresor yang datang tanpa perasaan emosional yang berlebihan dan dengan tingkat kecemasan yang lebih rendah disbanding dengan seseorang dengan kepribadian yang lebih feminim.

\section{Pendidikan}

Hasil penelitian yang mengalami hipertensi paling banyak pada tingkat SD yaitu 15 orang $(68,2 \%)$ dan paling sedikit pada tingakat SMP yaitu 3 orang $(13,6 \%)$. Menurut Notoatmodjo (2012). Pengetahuan adalah hasil 'tahu' dan ini terjadi setelah orang melakukan penginderaan terhadap satu objek tertentu. Penginderaan terjadi melalui panca indera manusia, yakni: indera penglihatan, pendengaran, penciuman, rasa dan raba dan sebagian besar pengetahuan manusia diperoleh melalui mata dan telinga.

Menurut penelitian yang dilakukan oleh Anggara dan Prayitno (2012) mengatakan bahwa ada hubungan antara tingkat pendidikan dengan tingkat kejadian hipertensi tidak semata-mata diakibatkan perbedaan tingkat pendidikan, tetapi tingkat pendidikan berpengaruh terhadap gaya hidup sehat dengan tidak merokok, tidak minum alkohol, dan lebih sering berolahraga (Kivimaki, 2004 dalam Yuliarti, 2007 dalam Anggara \& Prayitno, 2012). Tingginya risiko terkena hipertensi pada pendidikan yang rendah, kemungkinan disebabkan karena kurangnya pengetahuan pada pasien yang berpendidikan rendah terhadap kesehatan dan sulit atau lambat menerima informasi (penyuluhan) yang diberikan oleh petugas sehingga berdampak pada prilaku/pola hidup sehat. Pendidikan adalah suatu proses atau jenjang pengetahuan dengan pendidikan rendah sebagian jumlah terbanyak maka dapat disimpulkan bahwa pendidikan rendah dapat mempengaruhi tingkat pengetahuan yang dimiliki seseorang mengalami penanganan hipertensi yang dialami responden.

\section{Pekerjaan}

Hasil penelitian yang mengalami hipertensi paling banyak terjadi pada ibu rumah tangga (IRT) yaitu 12 orang $(54,5 \%)$ dan paling sedikit terjadi pada pedagang yaitu 2 orang $(9 \%)$. Menurut penelitian yang dilakukanoleh Agustin (2012) dikutip dalam Sinubu, Rondonuwu \& Onibala (2015).Hampir semua orang didalam kehidupan mereka mengalami stres berhubungan dengan pekerjaan mereka.Hal ini dapat dipengaruhi karena tuntutan kerja yang terlalu banyak (bekerja terlalu keras dan sering kerja lembur) dan jenis pekerjaan yang harus memberikan penilaian atas penampilan kerja bawahannya atau pekerjaan yang menuntut tanggung jawab bagi manusia.Beban kerja meliputi pembatasan jam kerja dan jam kerja yang diharuskan adalah 6-7 jam setiap harinya.Sisanya digunakan untuk keluarga dan masyarakat, istirahat, tidur dan lain-lain.Dalam satu minggu seseorang bekerja dengan baik selama 40-50 jam, lebih dari itu terlihat kecenderungan yang negatif seperti kelelehan kerja, penyakit dan kecelakaan kerja.Presentasi hipertensi lebih banyak terjadi pada ibu rumah tangga (IRT) karena kurangnya aktivitas sebagai sarana untuk mengurangi stress yang dialami, dibutuhkan sebuah aktivitas agar dapat mengalihkan rasa stress yang dirasakan sehingga rasa stress dapat berkurang dan tidak menjadi faktor terjadinya hipertensi.

\section{Pengaruh Konsumsi Jus Mentimun Terhadap Penurunan Tekanan Darah Pada Penderita Hipertensi}

Berdasarkan hasil penelitian 11 orang dari 22 orang responden yang diberikan intervensi didapatkan hasil $p$-value $=0,000$ ( $p$ value $<0,05)$. Hal ini menyatakan bahwa $\mathrm{H}_{\mathrm{a}}$ diterima dan $\mathrm{H}_{0}$ ditolak, yang artinya ada pengaruh konsumsi jus mentimun terhadap penurunan tekanan darah pada penderita hipertensi di desa Way Ngison.

Penelitian yang dilakukan oleh Fitrina (2013), kandungan pada mentimun yang mampu membantu menurunkan tekanan darah diantaranya kalium (potassium), magnesium, dan fosfor 
yang efektif mengobati hipertensi.Mentimun juga bersifat diuretik karena kandungan airnya yang tinggi sehingga membantu menurunkan tekanan darah (Dewi.S \& Familia.D, 2010 dalam Kunsul \& Munir, 2012). Kalium merupakan elektrolit intraseluler yang utama, dalam kenyataan, $98 \%$ kalium tubuh berada di dalam sel, $2 \%$ sisanya berada di luar sel, yang penting adalah $2 \%$ ini untuk fungsi neuromuskuler. Kalium mempengaruhi aktivitas baik otot skelet maupun otot jantung (Brunner \& Suddarth, 2001).

Sesuai penelitian yang dilakukan oleh Aisyah (2014), faktor yang mempengaruhi hipertensi antara lain ras, umur, jenis kelamin, obesitas, kurangnya aktivitas, kurangnya asupan kalium, kalsium, magnesium dan serat, asupan tinggi lemak, tinggi natrium, konsumsi alcohol berlebih, kebiasaan merokok, dan adanya riwayat hipertensi dalam keluarga. Berdasarkan penelitian diketahui bahwa diet yang menitik beratkan pada makanan rendah lemak, tinggi sayur dan buah-buahan mampu menurunkan tekanan darah sistolik sebesar 11,4 $\mathrm{mmHg}$ dan diastolik sebesar 5,5 mmHg pada penderita hipertensi.

Hasil penelitian lain menunjukkan bahwa dengan pemberian buah yang banyak mengandung kalium, kalsium, dan magnesium seperti pepaya, semangka, melon, dan belimbing demak dapat menurunkan tekanan darah secara signifikan. Peran kalium telah banyak diteliti dalam kaitannya dengan regulasi tekanan darah (Solanki. P, 2011 dalam Kusnul dan Munir, 2011) menyatakan beberapa mekanisme bagaimana kalium dapat menurunkan tekanan darah sebagai berikut: Kalium dapat menurunkan tekanan darah dengan menimbulkan efek vasodilatasi sehingga menyebabkan penurunan retensi perifer total dan meningkatkan output jantung.

Konsumsi kalium yang banyak akan meningkatkan konsentrasinya di dalam cairan intraseluler sehingga cenderung menarik cairan dari bagian ekstraseluler dan menurunkan tekanan darah (Amran Y dkk, 2010 dalam Kusnul \& Munir 2011). Kandungan pada mentimun yang mampu membantu menurunkan tekanan darah, kandungan pada mentimun diantaranya kalium (potassium), magnesium, dan fosfor efektif mengobati hipertensi.Selain itu, mentimun juga bersifat diuretik karena kandungan airnya yang tinggi sehingga membantu menurunkan tekanan darah.

Hipertensi merupakan penyakit yang tidak dapat disembuhkan melainkan hanya dapat dikontrol, maka diperlukan ketelatenan dan biaya yang cukup mahal. Seseorang yang mengalami hipertensi yang terus menerus dan tidak mendapatkan pengobatan dan pengontrolan secara tepat,menyebabkan jantung seseorang bekerja ekstra keras, akhirnya kondisi ini berakibatkan terjadinya kerusakan pada pembuluh darah jantung, ginjal, otak, dan mata. Tekanan darah yang selalu tinggi adalah salah satu faktor resiko untuk terjadinya stroke, serangan jantung dan gagal jantung.Mentimun merukan sayuran yang mudah didapat dan harganya pun murah.Dikalangan masyarakat umum, mentimun sudah lazim dikonsumsi untuk sekedar pelengkap hidangan, ini bisa dijadikan solusi untuk mengobati hipertensi secara non farmakologis (Kusnul \& Munir, 2011).

Kandungan mineral dari mentimun yaitu potassium, magnesium dan fospor dapat mengobati hipertensi.Selain itu mentimun juga bersifat diuretik karena kandungan airnya yang tinggi juga berfungsi sebagai penurun tekanan darah. Mengkonsumsi mentimun juga dapat menurunkan berat badan karena kandungan kalorinya yang rendah dan kaya akan serat (Fikri, 2008 dalam Usu, 2011 dalam Fitrina, 2013). Selain itu juga Vitamin C yang terkandung didalam mentimun berperan penting melalui proses metabolisme kolestrol, karna dalam proses 
metabolisme kolestrol Vitamin $\mathrm{C}$ dapat meningkatkan kadar glutation, yaitu asam amino yang bersifat antioksidan yang dihasilkan secara alami oleh sel tubuh. Vitamin C juga dapat meningkatkan kadar HDL dan berfungsi sebagai pencahar sehingga dapat meningkatkan pembuangan kotoran.

Penurunan tekanan darah setelah diberikan jus mentimun disebabkan karena pada umumnya hipertensi yang dialami pasien adalah hipertensi sebagai akibat faktor yang dapat dihindari seperti stress, kurang olah raga, penggunaan tembakau (riwayat merokok), kepekaan terhadap sodium. Sehingga dengan diberikannya jus mentimun dapat meningkatkan kadar kalium dalam darah yang dapat mendorong dikeluarkannya natrium melalui ginjal, diiringi oleh pengeluaran air. Pengurangan cairan dalam sirkulasi akan menurunkan tahanan perifer, sehingga dengan sendirinya tekanan darah akan turun. Mentimun dengan kaliumnya yang tinggi, memiliki khasiat meringankan penyakit hipertensi, terutama hipertensitivitas terhadap natrium. Pemberian jus mentimun ini lebih berpengaruh karena diiringi oleh perubahan pola hidup yang sehat dan seimbang, salah satunya dengan mengkonsumsi makanan rendah lemak dan kolesterol tetapi kaya akan serat yang dapat terkandung dalam sayur-sayuran atau buah-buah segar.

Penelitian ini juga didukung oleh beberapa factor yang tidak diteliti tapi memungkinkan dapat mempengaruhi pemberian terapi jus mentimun dalam penurunan tekanan darah yaitu factor internal dan factor eksternal.Factor internal terkait keadaan fisik dan psikis responden adalah motivasi responden yang dapat meningkatkan keinginan responden untuk meminum jus mentimun.Factor eksternal yang dapat mempengaruhi adalah segala hal yang berada diluar individu misalnya kesibukan masing-masing responden diluar rumah dapat mengakibatkan kurangnya atau tidak sesuai jadwal memimum jus mentimun yang sudah diberikan peneliti dengan penjelasan yang sudah diberikan.

\section{SIMPULAN}

Berdasarkan hasil penelitian yang berjudul pengaruh konsumsi jus mentimun dengan penurunan tekanan darah pada penderita hipertensi di desa Way Ngison tahun 2018 dapat diambil kesimpulan sebagai berikut: Karakteristik responden pada penelitian pengaruh konsumsi jus mentimun terhadap penurunan tekanan darah pada penderita hipertensi di desa Way Ngison, yang paling banyak mengalami hipertensi terjadi pada perempuan dengan tingkat pendidikan SD dan pekerjaan sebagai ibu rumah tangga (IRT). Rata-rata tekanan darah sistolik sebelum (pre-test) pada kelompok intervensi yaitu 168,8 dengan nilai terendah 140 dan nilai tertinngi 190. Sedangkan pada kelompok kontrol rata-rata tekanan darah sistolik sebelum (pretest) yaitu 170,00 dengan nilai terendah 150 dan nilai tertinggi 210. Rata-rata tekanan darah sistolik setelah (post-test) pada kelompok intervensi yaitu 137,27 dengan nilai terendah 120 dan nilai tertinggi 160. Sedangkan pada kelompok kontrol rata-rata tekanan darah sistolik setelah intervensi (post-test) yaitu 153,73 dangan nilai terendah 130 dan nilai tertinggi 190. Ada pengaruh yang signifikan dari pemberian jus mentimun dengan penurunan tekanan darah pada penderita hipertensi di desa Way Ngison. 
Vol 10 No 1 Januari 2021 | Page 22-32

\section{SARAN}

Berdasarkan kesimpulan di atas maka peneliti akan memberikan saran-saran terkait penelitian ini, adapun saran yang akan peneliti sampaikan sebagai berikut: Disarankan kepada institusi untuk menjadikan penelitian ini sebagai bahan penyuluhan mahasiswa saat memberikan informasi tentang kesehatan terkait tekanan darah tinggi atau hipertensi.

\section{DAFTAR PUSTAKA}

Bungin, B. (2014). Metodologi Penelitian Kuantitatif (2 ed.). Jakarta: Kencana Prenadamedia Group.

Dharma, K. K. (2015). Metodologi Penelitian Keperawatan. Jakarta: CV. Trans Info Media.

Elfandari, S. (2015). Efektifitas Jus Belimbing Manis dan Mentimun Terhadap Penurunan Tekanan Darah Pada Penderita Hipertensi Di Wilayah Kerja UPTD Puskesmas Kampung Bangka Kecamatan Pontianak Tenggara.

Fitrina, Y. (2013). Pengaruh Pemberian Jus Mentimun Terhadap Penurunan Tekanan Darah Pada Penderita Hipertensi Di Jorong Balerong Bunta Wilayah Puskesmas Sungai Tarab 1 Kecamatan Sungai Tarab Kabupaten Tanah Datar Tahun 2013. Keperawatan.

Hariyanto, A., \& Sulistyowati, R. (2015). Keperawatan Medikal Bedah 1. Jojakarta: Ar-ruzz Media.

Aisyah. (2014). Pengaruh Pemberian Jus Mentimun (Cucumis sativus l) Terhadap Penurunan Tekanan Darah Pada Penderita Hipertensi Wanita Usia 40-60 Tahun. Diakses Pada Tanggal 28 Maret 2018.

Infodatin. (2014). Hipertensi. Pusat Data dan Informasi Kementrian Kesehatan RI.

Kusnul, Z., \& Munir, Z. (2012). Efek Pemberian Jus Mentimun Terhadap Penurunan Tekanan Darah. Diakses Pada Tanggal 28 Maret 2018.

Klabunde, R. E. (2015). Konsep Fisiologi Kardiovaskular (Z. Djanun, Trans. E. Melinda, A. Sekartiwi \& C. K. Mulyadi Eds. 2 ed.). Jakarta: Penerbit Buku Kedokteran EGC.

Lebalado, L. P. (2014). Pengaruh Pemberian Jus Mentimun (Cucumis sativus L.) Terhadap Tekanan Darah Sistolik dan Diastolik Pada Penderita Hipertensi. Artikel Penelitian.

Aafandi, K. (2017). Pengaruh Senam Prolanis Terhadap Tekanan Darah Penderita Hipertensi Pada Lansia Di Wilayah Kerja Puskesmas Totomulyo Kabupaten Tulang Bawang Barat Tahun 2017. Diakses pada Tanggal 28 Maret 2018.

Mujahidullah, K. (2012). Keperawatan Geriatrik. Yogyakarta: Pustaka Pelajar.

Notoatmodjo, S. (2014). Metodologi Penelitian Kesehatan (2 ed.). Jakarta: Rineka Cipta.

Oemiati, R., Rini, K. F., Utami, N. H., \& Narendro. (2013). Pokok-pokok Hasil Riskesdas Provinsi Lampung 2013. 


\section{Jik JURNALILMAA KESEEATAN}

Vol 10 No 1 Januari 2021 | Page 22-32

Ponggohong, C. E., Rompas, S. S. J., \& Ismanto, A. Y. (2015). Pengaruh Pemberian Jus Mentimun Terhadap Tekanan Darah Pada Penderita Hipertensi Di Desa Tolombukan Kec. Pasan Kab. Minahasa Tenggara Tahun 2015. Keperawatan, 3.

Novitaningtyas, T. (2014). Hubungan Karakteristik (umur, jenis kelamin, tingkat pendidikan) dan Aktivitas Fisik Dengan Tekanan Darah Pada Lansia Di Kelurahan Makamhaji Kecamatan Kartasura Kabupaten Sukoharjo. Diakses Pada Tanggal 20 Oktober 2018.

Sugiyono. (2016). Statistika Untuk Penelitian. Bandung: CV. Alfabeta.

Syamsudin. (2011a). Buku Ajar Farmakoterapi Kardiovaskular dan Renal. Jakarta: Salemba Medika.

Syamsudin. (2011b). Buku Ajaran Farmakoterapi Kardiovaskular dan Renal. Jakarta Selatan: Salemba Medika.

Tjiptaningrum, A., \& Erhadestria, S. (2016). Manfaat Jus Mentimun (Cucumis sativus L.) Sebagai Terapi Untuk Hipertensi. 5.

Triyanto, E. (2014). Pelayanan Keperawatan Bagi Penderita Hipertensi Secara Terpadu. Yogyakarta: Graha Ilmu.

Yu-Chi, Wu., Keng-Yu Shih. The Effects of Gender Role on Perceived Job Stress. The Journal of Human Resource and Adult Learning Vol. 6, Num. 2, December 2010.

Riskesdas (Riset Kesehatan Dasar). 2013. Laporan Hasil Riset Kesehatan Dasar. Diakses Pada Tanggal 18 Oktober 2018.

Sinubu, R. B., Rondonuwu, R., \& Onibala, F. (2015). Hubungan Beban Kerja Dengan Kejadian Hpertensi Pada Tenaga Pengajar Di SMA N 1 Amurang Kabupaten Minahasa Selatan. Vol. 3, No. 2, Mei 2015.

Anggara, F. H. D., \& Prayitno, N. (2013). Faktor-Faktor Yang Berhubungan Dengan Tekanan Darah Di Puskesmas Telaga Murni, Cikarang Barat Tahun 2012. Jurnal Ilmiah Kesehatan, 5 (1), Januari 2013. 